\title{
Correlated evolution of mating behaviour and morphology in large carpenter bees (Xylocopa)*
}

\author{
Remko LEYs $^{1,2}$, Katja HoGENDOORN ${ }^{3}$ \\ ${ }^{1}$ Evolutionary Biology Unit South, Australian Museum, North Terrace SA 5000, Adelaide, Australia \\ ${ }^{2}$ School of Earth and Environmental Sciences, University of Adelaide, Australia \\ ${ }^{3}$ School of Agriculture, Food and Wine, The University of Adelaide, Adelaide SA 5005, Australia
}

Received 12 June 2007 - Revised 25 September 2007 - Accepted 3 October 2007

\begin{abstract}
Carpenter bees (Xylocopa) display variation in mating strategies. In several subgenera males defend territories that contain resources for females. In other subgenera males defend a small non-resource territory. Here, we investigate the correlation between three morphological traits and mating strategy. We found associations between mating strategy and male eye size, size of the mesosomal gland and sexual colour dimorphism, as well as correlative evolution between the morphological characters. Analysis of the evolutionary pathways shows that resource defence, small glands and monomorphic sexes are ancestral states. Increases in gland size seem to precede or coincide with changes in mating behaviour, but changes towards sexual dimorphism follow changes in mating behaviour. Once a non-resource defence strategy with correlated morphology has evolved there are no reversals to the ancestral states. We discuss the types of selection that may have caused these correlative changes.
\end{abstract}

correlated evolution / molecular phylogeny / mating / sexual selection / Xylocopa

\section{INTRODUCTION}

The elaboration of male traits, such as sexual dimorphism in size or colour, secondary sexual characters and ornamentation is mostly considered to reflect the action of sexual selection (Darwin, 1871). Sexual selection comprises intra-sexual selection through malemale competition and inter-sexual selection through female choice. In addition, but often forgotten, sexual dimorphism can evolve through natural selection (e.g. Temeles et al., 2000; Kruger, 2005; Stuart-Fox and Moussalli, 2007). However, because there are strong reciprocal causal links between mating systems and sexual selection (Andersson, 1994),

Corresponding author: R. Leys,

Leijs.Remko@saugov.sa.gov.au

* Manuscript editor: Eduardo A.B. Almeida

Online material is available at:

http://www.apidologie.org comparative analysis of related species with different mating strategies are needed to elucidate patterns of causal variables (e.g. Brown et al., 1997; Markow, 2002; Kruger et al., 2007).

In this study, we use phylogenetic methods to evaluate the correlation between mating strategies and sexually selected traits in the group of large carpenter bees of the genus $X y$ locopa (Hymenoptera, Apidae). The genus is eminently suitable for analyses of such correlated evolution because it is very speciose (approximately 470 species divided into 31 subgenera) and because mating strategies vary considerably between species (e.g. Gerling et al., 1989; Michener, 1990; Minckley, 1994). Mating behaviour has been described for 38 species belonging to 16 different subgenera (Tab. I supporting information). A wellresolved molecular phylogeny that includes 27 subgenera has recently become available 
(Leys et al., 2002). This allows testing of phylogenetic correlations between mating behaviour and morphological traits.

Using the terminology developed by Alcock et al. (1978) and Eickwort and Ginsberg (1980), the different strategies that males of carpenter bees use to encounter receptive females are: (1) non-territorial patrolling of nests or flowers, ('non-defence polygyny or patrolling' - P); (2) territorial defence of resources (flowers, nests) or of females inside nests ('resource defence polygyny - RD'); and (3) territorial behaviour at locations that do not contain any resources for females ('non-resource defence polygyny'NRD), a strategy that has also been called a 'dispersed lek' system (Bradbury, 1981) because females are able to assess the quality of males by comparing displaying males in dispersed territories.

Several authors have suggested associations between mating strategies and morphological characters. The main characters are: (i) Size of the mesosomal glands. The exocrine products from the mesosomal glands are used as a long range sex-attractant pheromone (Gerling et al., 1989; Minckley et al., 1991; Alcock and Johnson, 1990). Enlarged mesosomal glands are often encountered in species displaying non-resource defence behaviour (Minckley, 1994). (ii) Sexual colour dimorphism. In many species males and females have approximately the same colouration, but in others the colouration differs considerably. In dimorphic species males are usually entirely covered with light pubescent hairs (e.g. white, yellow or olive green), in contrast with females that are mainly black often with bands of light coloured pubescence (e.g. in X. (Koptortosoma) and X. (Neoxylocopa)). It has been suggested that the light colouration in males could function as a visual recognition cue for females or to decrease thermal stress during the energetically expensive hovering flights (Minckley et al., 1991). Sexual colour dimorphism therefore seems to be associated with species in subgenera that perform non-resource defence behaviour. (iii) Male eye size. In several species males have large eyes compared to the females. It is likely that vision may be an important part of mate encounters in RD, where males give chase to females and conspecific males (Frankie et al., 1979; Minckley, 1994). Therefore large eye size of males may be associated with resource defence behaviour, as was suggested by Osten (1989) and Minckley (1994). Minckley (1994) also suggested an association between enlarged glands and relatively small eyes.

In this paper we apply phylogenetic methods to investigate the associations between mating behaviour and the morphological characters mentioned in the previous paragraph. Specifically, we test whether there has been correlated evolution in Xylocopa between mating strategy and (a) size of mesosomal glands in males, (b) sexual colour dimorphism and (c) relative male eye size. We hypothesize associations between non-resource defence and enlarged glands, presence of colour dimorphism and small eyes, and vice versa, between resource defence, small glands, absence of colour dimorphism and enlarged eyes. Furthermore, we reconstruct the ancestral character states for the genus and investigate the evolutionary pathways from the reconstructed ancestral states to the derived character states, including possible reversals, of all pairs of characters.

\section{METHODS}

\subsection{Taxa examined}

We used the dataset supplied by Leys et al. (2002) supplemented with representatives of several additional subgenera, as well as additional species in the subgenus $X$. (Koptortosoma). Forty-five Xylocopa species, belonging to 28 subgenera are now included in the molecular data set. Information about mating strategies is available for 20 of these species (16 subgenera). These species represent all major taxonomic divisions in the genus, and represent all recognized mating behavioral patterns and associated morphological variation. References for mating strategies are listed in Table I of the online supplementary information.

\subsection{Molecular methods}

DNA extraction, PCR amplification and sequencing were performed as described in Leys et al. 
Table I. Correlation between behavioural and morphological characters using Bayes factors. Any Bayes Factor with a positive ratio greater than 2 is considered positive evidence, greater than 5 is strong evidence, and greater than 10 is very strong evidence for correlated evolution (Pagel and Meade, 2006).

\begin{tabular}{lccc}
\hline & \multicolumn{2}{c}{ Harmonic mean (Log) } \\
Correlated Characters & $\begin{array}{c}\text { Independent } \\
\text { analysis }\end{array}$ & $\begin{array}{c}\text { Dependent } \\
\text { analysis }\end{array}$ & $\begin{array}{c}\text { Bayes } \\
\text { Factor }\end{array}$ \\
\hline Mating - Mesosomal glands & -34.6 & -27.2 & 14.6 \\
Mating - Sexual colour dimorphism & -38.1 & -30.7 & 14.8 \\
Mating - Male eye size & -38.7 & -35.0 & 7.3 \\
Mesosomal glands - Sexual colour dimorphism & -43.3 & -38.7 & 9.1 \\
Mesosomal glands - Male eye size & -44.5 & -40.7 & 7.4 \\
Male eye size - Sexual colour dimorphism & -47.7 & -44.1 & 7.1 \\
\hline
\end{tabular}

(2002). The present data set is based on CO1, $C y t-b, E F-1 \alpha$ and PEPCK (GenBank Acc. No.'s. AY005222 - AY005329), and new sequences are available on Genbank (Acc. No.'s EU180073 EU180132).

\subsection{Phylogenetic analyses}

Phylogenetic analyses of aligned sequence data, of $2437 \mathrm{bp}$, were carried out using the program MRBAYES v.3.1 (Huelsenbeck and Ronquist, 2001). A General Time Reversible model (Rodriguez et al., 1990), with a proportion of invariant sites and unequal rates among sites (Yang, 1996), modeled with a gamma distribution $(\mathrm{GTR}+\mathrm{I}+\mathrm{G})$ in MODELTEST (Posada and Crandall, 1998), was found to be the most appropriate model to use in the Bayesian analyses. The MRBAYES analysis was done by applying different parameter optimizations in an unlinked analysis, using default uninformative priors, for the following eight partitions: first (1), second (2) and third (3) codon positions of the mitochondrial data, first and second codon positions combined of the EF1alpha (4) and PEPCK (5) data, third codon positions of the EF1alpha (6) and PEPCK (7) data, and intron data of PEPCK (8). Four chains were run simultaneously for 3 million generations in two independent runs, sampling trees every 50 generations. TRACER version 1.3 (Rambaut and Drummond, 2005) was used to determine effective sample size (ESS) of the parameters during the MRBAYES runs. After 3 million generations all parameters had reached their ESS, and the potential scale reduction parameter was approximately one for all parameters, indicating Bayesian runs had converged and that a sufficient sample of the posterior distribution had been obtained. A burn-in of 30000 iterations was chosen for each independent run of MRBAYES.

\subsection{Analyses of correlated evolution}

To study correlated evolution we used BAYESTRAITS, a computer package for analyzing trait evolution among species on phylogenetic trees (available from www.evolution.rdg.ac.uk). This package allows analysis of pairs of discrete binary characters using reversible jump Markov Chain Monte Carlo (rj-MCMC) methods. The theory and methods, including model testing, are described in depth in Pagel and Meade (2006) and the manual of BAYESTRAITS. Here we will suffice with a concise description of the methods.

Two characters with binary states can have four different combinations of character states, as shown in Figure 2. If we assume that states of both characters cannot change simultaneously, then there are eight different rates of transitions, which are denoted in Figure $2 \mathrm{a}-\mathrm{f}$ by q12, q21, q13 etc. Transition rates can be classified into different rate classes, whereby different combinations of transitions can have the same, different or zero rates. In these analyses each combination of transitions is considered a different model of correlated evolution. One of those models were transition rates are restricted as follows: $\mathrm{q} 12=\mathrm{q} 34, \mathrm{q} 21=\mathrm{q} 43, \mathrm{q} 13=\mathrm{q} 24$ and $\mathrm{q} 31=\mathrm{q} 42$, indicating that a transition of one character is completely independent of the other character, illustrates the independent model of evolution. Overall, considering the number of transitions and the combinations of rate classes there are thousands of possible models. The rj-MCMC method selects the models of correlated evolution with the highest likelihoods given a set of phylogenetic trees. 
To incorporate phylogenetic uncertainty we used the last 100 trees sampled from one of the runs of the bayesian phylogenetic analysis as input for the Bayestraits analyses. BayesTraits was run using the independent and dependent Discrete model for every pair of characters using the MCMC analysis method. A reversible-jump hyperprior with exponential distribution between 0 and 30 was used. We run the MCMC chain for 20 million iterations with a sampling period of 300 and a burn-in of 70000. The ratedev parameter was set to 20 in order to obtain the recommended acceptance rates in the MCMC chain of 20-40\%. X. (Diaxylocopa) truxali was omitted from the analyses because of lack of data. Because the taxa X. (Lestis) aeratus and X. (Schoenherria) micans are known to have polymorphic mating strategies (Tab. I supporting information), we ran successive analyses for each mating strategy states for these taxa. The outcome of these analyses only differed with respect to the association between mating strategy and gland size. In all other cases, the mating strategy assigned to these polymorphic species did not influence the outcome of the analyses and in these cases the results of one of the two analyses is presented (species classified as RD).

To test the hypothesis of correlated evolution we used the BayesFactor as a test statistic to compare the likelihoods from the independent and dependent analyses, whereby: BayesFactor $=2[\log$ (harmonic mean of the dependent model)- $\log$ (harmonic mean of the independent model)]. Any BayesFactor with a positive ratio greater than 2 is considered positive evidence, greater than 5 is strong evidence, and greater than 10 is very strong evidence for correlated evolution (Pagel and Meade, 2006).

\subsection{Character states}

Table I, supporting information, shows information collected from the literature about mating strategies and morphological characters including male mesosomal glands, male eye size, and sexual colour dimorphism.

The three mating strategies, i.e. patrolling or non-defence $(\mathrm{P})$, resource defence $(\mathrm{RD})$ and nonresource defence (NRD) are described above. To enable analysis of correlated change, the mating strategy data set was made dichotomous by pooling the patrolling $(\mathrm{P})$ strategy with the resource defence (RD) strategy. This is justified by the fact that both are resource-based behaviours, and by the observation that many of the species in which the resource defence strategy was observed, patrolling was an alternative strategy (Tab. I supporting information). The logic here is that a bee employing resource based behaviour needs to patrol its environment first before it can decide which resource patches are worth defending, vis a vis the likelihood of encountering receptive females (Leys, 2000b).

For analysis of mesosomal glands, morphological data from Minckley (1994) were used. Minckley (1994) recognises six different character states in the mesosomal gland reservoir of the males in carpenter bees: completely absent (type 0 ) to five different categories based on the relative size of the reservoir, place of opening and tubule arrangement. For the following subgenera, not examined by Minckley, the mesosomal gland reservoir types were determined by dissection of the males: $X$. (Lestis) aeratus (type 2, Leys, 2000a), X. (Biluna) (type 5), X. (Hoploxylocopa) acutipennis (type 5), $X$. (Mesotrichia) flavorufa (type 5), X. (Cyphoxylocopa) ocularis (type 5) and X. (Zonohirsuta) collaris (type 4). To be able to use these data in the BayesTraits Discrete analyses the mesosomal gland reservoir types were pooled into binary character states: mesosomal gland types $0-2$ were classified as reduced/absent and types 3-5 as enlarged.

Male eye size was taken from Hurd and Moure (1963), who classified eyes as 'enlarged' if the maximum width of the eye was larger than or equal to the minimum upper interorbital distance, and 'small' if the maximum width of the eye was less than the minimum upper interorbital distance (Hurd and Moure, 1963, p. 24 and p. 26). In species with enlarged male eyes, male eye size is markedly increased compared to the eye size of females.

Sexual colour dimorphism was considered to be present when the males were entirely covered with light pubescent hairs, while the females are largely black with some light banding. Those species that have males that are partially covered with light hairs while leaving a large part of the abdomen black, for example X. (Xylocopoides) virginica and $X$. (Schoenherria) micans, were was classified as monomorphic.

\section{RESULTS}

\subsection{Phylogenetic reconstruction}

Analyses of DNA sequence data resulted in a well-resolved phylogeny. A consensus tree 


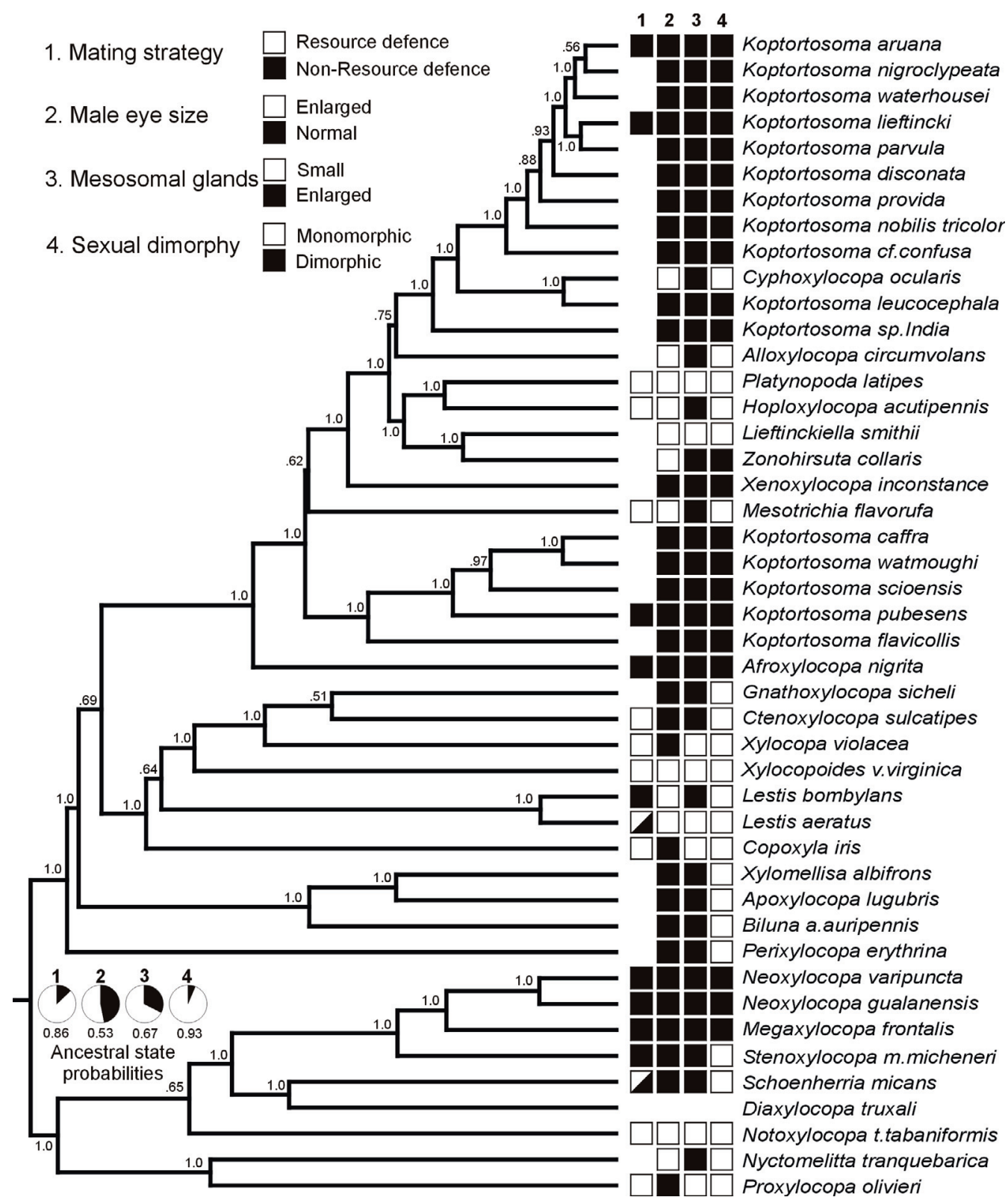

Figure 1. Bayesian phylogeny of Xylocopa based on a combined molecular data set of four genes (CO1, $C y t-b, E F-1 \alpha$ and $P E P C K)$. The numbers at the nodes represent the posterior probabilities. The probabilities of the ancestral states are indicated near the root of tree. Character states (most likely ancestral state in black) for mating strategy and three morphological characters are shown near the species names. A review of Xylocopa mating strategies and morphological character states are presented in Table I of the online supplementary information. 
based on the last 100 sampled trees of one of the Bayesian runs is presented in Figure 1. The main differences between the present topology and previously published maximum parsimony and maximum likelihood analyses (Leys et al., 2002) are in clades with posterior probabilities smaller than 0.71 in the previous phylogeny. Most of the posterior probabilities in the present phylogeny are high $(82 \%$ of the nodes have a posterior probability $>0.9$ ) and therefore the topology suits as a reliable framework for comparative evolutionary studies. Moreover, in the analyses of correlative evolution phylogenetic uncertainty was taken into account by incorporating the 100 last sampled trees of the Bayesian phylogenetic analysis.

\subsection{Correlated change and ancestral characters}

\section{Correlated change}

BayesFactor tests for all combinations of characters showed significant correlation between mating strategies and each of the morphological characters (BayesFactors $>5$ for all analyses; Tab. I). In particular mating strategy and mesosomal gland size, and mating strategy and sexual colour dimorphism revealed very strong positive evidence for correlated evolution (BayesFactor $>10$ ). The correlations between each of the morphological characters were also significant (all BayesFactors $>5$, Tab. I).

Table III online supporting information shows harmonic means and character state probabilities of the root resulting from the independent and dependent DiscreTE analyses, as well as the mean rate of character state changes in the dependent analyses.

\section{Ancestral states for mating systems and morphological characters}

The probabilities for the ancestral state of each of the traits were calculated by adding individual state probabilities in each dependent analysis and averaging among the dependent analyses (see supplementary data). The ancestral state for mating strategy is resource based
$(P=0.86)$, which is supported by all independent and dependent analyses. Similarly, the ancestral state for sexual colour dimorphism is 'monomorphic', the absence of sexual dimorphism $(P=0.93)$.

In the cases of eye size and gland size, the ancestral states are less unambiguous. For male eyes size the grand average of the probabilities for each character state over all tests was 0.53 for enlarged eyes and 0.46 for small eyes (Tab. III online supporting material). Therefore, the ancestral character state remains unclear and we will discuss the likely evolutionary pathway for each possible ancestral state.

For mesosomal gland size the grand average of the probabilities for the ancestral character state over all tests was 0.67 for small glands and 0.33 for enlarged glands (see supplementary data). Because the occurrence of enlarged mesosomal glands is a unique character in carpenter bees (it does not occur elsewhere in the Xylocopinae) we will treat small glands as the ancestral character state.

\subsection{Evolutionary pathways of changes in mating strategy and morphological traits}

For all pairs of characters we have visualized the results in flow diagrams that show the probable evolutionary pathways from the reconstructed ancestral states (Fig. 2a-f). In the following paragraphs we discuss these results in more detail.

\section{Mating strategy and mesosomal gland size}

Figure 2a. The assumed ancestral states are resource based with small gland sizes $(\mathrm{R}, \mathrm{S})$. There are two different evolutionary paths to consider, when the species $X$. (Lestis) aeratus and X. (Schoenherria) micans with polymorphic mating strategies were treated as NRD (line a) or when the mating strategy was set to RD (line b). In the first case (line a), posterior distribution of the rate parameters suggests that either the glands or the mating strategy may change first (q21 q24) and that 


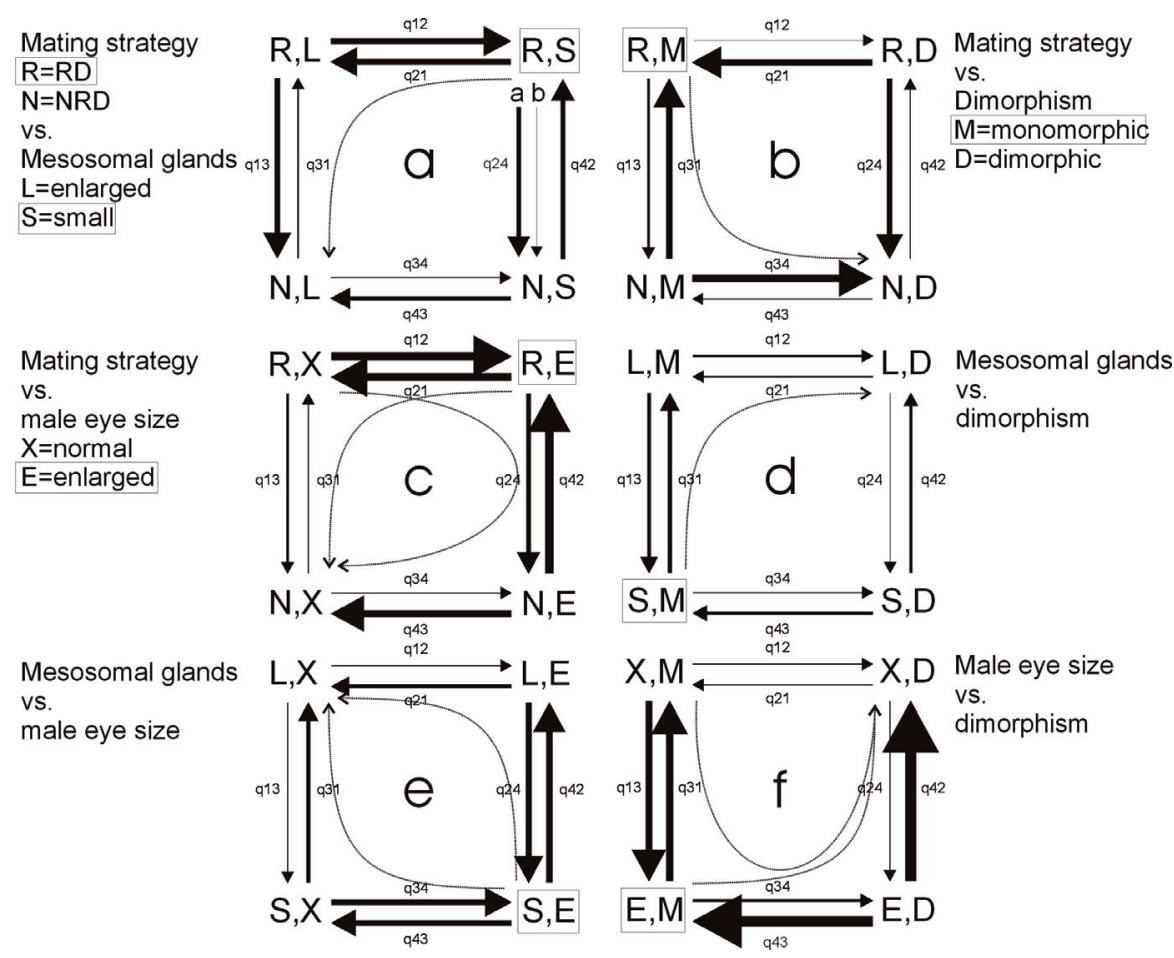

Figure 2. The probable evolutionary pathways for the character states based on BAYESTRAITS analyses. Character states are presented by abbreviations as indicated. The most likely combination of ancestral character states is indicated in a box. The width of the arrows is commensurate to the estimated rate of transition between the character states. In $2 \mathrm{a}$, arrow (a) represents the rate when assuming that the two polymorphic species $X$. (Lestis) aeratus and X. (Schoenherria) micans have a NRD strategy, arrow (b) assumes a RD strategy.

this change created a potential for a change in the other character. However, in the second case (line b), the posterior distribution of the rate parameters strongly suggest that glands changed first (q21>q24), and that this would set the stage for the evolution of a NRD mating system. In this case the alternative route, in which NRD evolves first is not supported (q24 0). Rates (q31 and q34) leading back from the derived state of NRD and large glands $(\mathrm{N}, \mathrm{L})$ to intermediate states are both extremely small. Large rates leading away from the intermediate state of $(\mathrm{N}, \mathrm{S})$ are likely to be artefacts of the method because the statistical model calculates the likelihood at internal nodes over all possible states (cf. Pagel and Meade, 2006). This combination of character states is only found for the polymorphic $X$. (Lestis) aeratus when the species is assigned to NRD state.

\section{Mating strategy and sexual colour dimorphism}

Figure $2 \mathrm{~b}$. The reconstructed ancestral state is resource defence and monomorphic sexes (R,M). Posterior distributions of the rate parameters suggests that the mating strategy changed first (q13 is approximately 100 times q12) and that this change created a selective force for the evolution of sexual dimorphism. From a stage of NRD and monomorphic sexes $(\mathrm{N}, \mathrm{M})$ pathways are open to revert to the ancestral state (q31) or to develop sexual colour dimorphism (q34). Rates (q43 and q42) leading back from the derived state of NRD and dimorphism (N,D) to either of the intermediate states are both extremely small. The rates q21 and q24 leading away from the intermediate state of RD and sexual dimorphism $(\mathrm{R}, \mathrm{D})$ 
arise as an artefact of the method because the statistical model calculates the likelihood at internal nodes over all possible states (cf. Pagel and Meade, 2006). This combination of traits was not found in any of the species included in our dataset (Tab. I online supporting information).

\section{Mating strategy and male eye size}

Figure 2c. The ancestral state for mating was resource defence, but for male eye size it was undecided. If we assume that the ancestral state is enlarged eyes (R,E), posterior distributions of the rate coefficient are inconclusive with respect to the evolutionary pathway (q21 q24). However, should mating strategy change to NRD while maintaining large eyes $(\mathrm{N}, \mathrm{E})$ then this seems an unstable situation with large rates of reversals in mating strategy or change towards small eyes.

If we assume that the ancestral state for males eyes size is normal eyes $(\mathrm{R}, \mathrm{X})$, then the evolutionary pathway would be the development of large eyes first (q12>q13), after which changes to NRD would occur (q24). However, there would be frequent reversals from this derived state to each of the neighbouring states $(\mathrm{N}, \mathrm{X})$ and $(\mathrm{R}, \mathrm{E})$.

It seems that male eye size can become reduced irrespective of mating strategy (q21 q43), but that acquisition of enlarged eyes is more likely when the species have an RD strategy than when they have an NRD strategy $(\mathrm{q} 12>\mathrm{q} 34)$.

Whatever the ancestral state of the eyes may be, changes away from $(\mathrm{N}, \mathrm{X})$ are unlikely as q31 and q34 are both extremely small.

\section{Mesosomal gland size and sexual dimorphism}

Figure 2d. The reconstructed ancestral states are small glands and monomorphic sexes $(\mathrm{S}, \mathrm{M})$. Posterior distributions of the rate coefficients suggests that the glands changed first (q31 > q34), after which changes could occur to either reverse back to the ancestral state or to develop colour dimorphism (q12 q13). In addition, the rate of gaining large glands is independent of whether or not the species is dimorphic (q31 q42).

\section{Mesosomal gland size and male eye size}

Figure 2e. The reconstructed ancestral states are small glands and enlarged eyes $(\mathrm{S}, \mathrm{E})$ or small glands and normal eyes (S,X). From $(\mathrm{S}, \mathrm{E})$, posterior probabilities suggest high rates (q42) of gaining enlarged glands $(\mathrm{L}, \mathrm{E})$ but also high rates (q43) of eye reduction $(\mathrm{S}, \mathrm{X})$. The state of large glands and normal eyes $(\mathrm{L}, \mathrm{X})$ can therefore be achieved through both evolutionary pathways. The data suggest that changes in eye size from enlarged to normal are independent of gland size (q21 q34), and that loss of large glands occurs more frequently in species with enlarged eyes than in species with small eyes (q24>q31). From $(\mathrm{L}, \mathrm{X})$, the rates towards enlarged eyes $(\mathrm{L}, \mathrm{E})$ or small glands $(\mathrm{S}, \mathrm{X})$ are very small (q12 and q13).

\section{Male eye size vs. sexual dimorphism}

Figure 2f. The reconstructed ancestral states are enlarged eyes or small eyes and monomorphic sexes $(\mathrm{E}, \mathrm{M})$ or $(\mathrm{X}, \mathrm{M})$. Eyes can become small independent of whether the species are monomorphic or dimorphic (q31 q42). However there is a strong reversal rate when species are monomorphic (q13), which is not found under dimorphism (q24). In addition, the rate from normal eyed monomorphic species to normal eyed dimorphic species (q12) is virtually zero. This suggests that the state of normal eyes and sexual dimorphism is gained by first changing dimorphism (q34) and then reducing male eye size (q42). Reversal rates from the state of small eyes and dimorphism $(\mathrm{X}, \mathrm{D})$ to either $(\mathrm{X}, \mathrm{M})$ or $(\mathrm{E}, \mathrm{D})$ are close to zero.

\section{DISCUSSION}

The analyses show a significant association between changes in mating strategy and the male morphological characters, i.e. mesosomal gland size, sexual colour dimorphism and 
eye size. Below we discuss the observed correlations, the ancestral states and evolutionary pathways for each of the morphological characters in relation to mating strategy. We then discuss whether the morphological traits would be under inter-sexual, intra-sexual or natural selection, and we develop a hypothesis for the selective factors underlying the different mating strategies.

\subsection{Mating and gland size}

Several authors have suggested a correlation between mating strategy and gland size (e.g. Gerling et al., 1989; Alcock and Johnson, 1990; Minckley et al., 1991; Minckley, 1994). These suggestions are confirmed by our analyses. As a rule, males of species that are known non-resource defenders have strongly enlarged mesosomal glands while males of species that are specialist resource defenders have small glands. However, there are some exceptions. X. (Mesotrichia) and X. (Hoploxylocopa) have resource defence and large glands (type 5), and species belonging to $X$. (Ctenoxylocopa) and $X$. (Schoenherria), that are also known resource defenders have large (type 3) mesosomal glands. A possible explanation for some of these exceptions can be found in a study on $X$. (Schoenherria) micans (McAuslane et al., 1990). Males of the first generation of this bivoltine species predominantly defend patches of flowers and show reduced activity of the mesosomal glands. However, in the second generation, the males use a non-resource defence strategy and the glands produce larger amounts of exocrine products. Thus, the correlation between gland size and mating strategy may superficially seem imperfect if species have mixed strategies that have not as yet been described. However, this explanation does not hold for X. (Ctenoxylocopa) sulcatipes, a well-studied species with enlarged mesosomal glands that has never been seen to perform non-resource defence behaviour (Velthuis and Gerling, 1980; Gerling et al., 1983; Stark, 1990; pers obs; M. Rosenboim, pers. com.). Males of this species mark their territories near flowers with a mandibular gland secretion (Hefetz, 1983) that attracts females (Gerling et al., 1989). Similarly $X$. (Neoxylocopa) hirsutissima uses exocrine secretions from other glands to attract females (Velthuis and Camargo, 1975a, b). By analogy, the mesosomal glands of $X$. (Ctenoxylocopa) sulcatipes and other species that have large glands and resource defence behaviour (X. (Hoploxylocopa) acutipennis and X. (Mesotrichia) flavorufa) may have a similar function in resource defence behaviour. Our results could have been influenced by lumping the type 3, 4 and 5 glands, while perhaps type 4 and 5 are more closely linked to NRD behaviour, because these seem to function to produce large amounts of excretion per unit of time to produce a strong signal detectable from long distances, while flower marking, often by species with type 3 glands, suffice with lower amounts of excrete per time, because it may only be intended to act on short distances. Bioassay studies for different species are needed to be able to interpret the evolutionary correlations.

The ancestral state for mating behaviour was resource defence, and small glands as the ancestral state had more support than large glands. A derived state of large glands is further supported by the fact that the large glands are a unique character for the Xylocopini (Minckley, 1994), not found in any close relatives. Gerling et al. (1989) presented an evolutionary scenario for the evolution of mating behaviour in which they also implicitly assumed that resource defence and small glands were ancestral.

Our data suggest that increases in gland size preceded transitions from resource defence to non-resource defence. However, it is likely that this is in actual fact a stepwise process. An initial change from resource defence to a mixed strategy that involves a combination of hill topping and resource defence could set the stage for changes in glands from size 1 to size 2, as was found in $X$. (Lestis) aeratus. More extensive non-resource defence would then require the males to develop substantially more attractant and therefore larger glands, as suggested by the study of McAuslan (1990) on X. (Schoenherria) micans (see above). Thus, the result that changes in gland size preceded changes in mating strategy may have been partly shaped by our 
dichotomous classifications of character traits that are in fact not dichotomous. Unfortunately tests for correlated evolution including more than two states do not as yet exist.

\subsection{Mating and sexual dimorphism}

As a rule, males of species that are known non-resource defenders show sexual colour dimorphism and while males of species that are specialist resource defenders are not sexually colour dimorphic, as was suggested by Minckley et al. (1991). Exceptions are X. (Schoenherria) micans and $X$. (Lestis) aeratus that show a mixed strategy and no dimorphism, and $X$. (Lestis) bombylans which has non-resource defence and lacks dimorphism. Exceptions in the other direction (resource defence by sexually dimorphic species) do not occur.

The ancestral state was monomorphic sexes. The evolutionary pathways analysis suggests that changes in mating strategy towards non-resource defence preceded changes towards sexual dimorphism. Again it is likely that such changes come about in a stepwise fashion, which is suggested by the fact that males belonging to species with mixed strategies (e.g. X. (Schoenherria) micans and $X$. (Lestis) aeratus) have males that are partially covered with light hairs

\subsection{Mating and eye size}

The correlated evolution of eye size and mating strategy corroborates suggestions by Osten (1989) and Minckley (1994). The ancestral character state for male eye size remained unclear. Although derived states of the other characters (large glands, sexual dimorphism and non resource defence) frequently coincide with normal eye size, this is no reason to expect that large eye size would be ancestral. It is conceivable that normal eyes is the ancestral state, and that in some species enlarged eyes have evolved in resource defenders as a response to high intra- or interspecific competition for resources.

In summary, for all combinations of character traits except those involving male eye size, evolutionary pathways could be unambiguously reconstructed on the basis of the probability of the transitions from one state to the other. Changes in gland size preceded changes in mating strategy, and changes in mating strategy preceded changes sexual dimorphism.

It is noteworthy that in the three reconstructions of the rates of character state changes correlated with mating strategy, the derived states of NRD mating strategy in combination with enlarged mesosomal glands and sexual dimorphism all have very slow, or non-existing rates of reversal to any of the intermediate states. The result of this lack of reversal to the intermediate stages is that certain combinations of character traits are very rare. Specifically, the combinations 'small glands and NRD' and 'sexual dimorphism and RD' were not found.

\subsection{Selective pressures for morphological characters and mating strategies}

Much discussion has been devoted to the relative importance of inter, intra, and natural selection in shaping the differences between males and females (e.g. Höglund, 1989; Björklund, 1990; Brown et al., 1997; Hardy and Mayhew, 1998; Johnson and Lanyon 2000; Temeles et al., 2000; Kruger, 2005; Stuart-Fox and Moussalli, 2007). Below we use functional explanations of the traits to speculate about the nature of the selective pressures involved in their evolution.

\subsection{Gland size and intersexual selection}

The main function of the gland products is attracting females over relatively long distances (Gerling et al., 1989; Minckley et al., 1991; Alcock and Johnson, 1990), it seems likely that the large glands are the result of inter-sexual selection, where the male with the largest (or best smelling) odour bouquet receives most attention from females in his territory. 


\subsection{Eye size - intra- or intersexual selection}

Males in resource defence territories are very active in chasing any visitor in their territory (Frankie et al., 1979; Minckley, 1994), whether male or female. If eye size is important for rapid spotting, because larger eyes mean an increased field of vision, and would there fore enhance detection of intruders, then eye size is most likely a result of sexual selection rather than natural selection. Large eyes could be the result of intra-sexual selection when their most important function is to rapidly spot intruder males and chase them away. Not excluding this possibility, large eyes could also arise through cryptic inter-sexual selection, if males that rapidly spot females have a selective advantage.

\subsection{Sexual dimorphism - natural selection?}

One may consider the association of the non-resource defence strategy, sometimes also referred to as dispersed lek mating system (Bradbury, 1981; Alcock and Smith, 1987), with sexual colour dimorphism to be a consequence of female choice. However, with Minckley (1994), we hypothesise that female choice is acting mainly on the mesosomal gland products and that the sexual colour dimorphism is more likely the result of natural selection. Minckley (1994) suggests that male colouration may be selected because males with light colours are likely to cope better with heat stress. We propose that the colouration serves a camouflage in the sunlit spots between leaves and branches, which males frequently select as territories (Gerling et al., 1989, pers. obs.). The need for cryptic colouration becomes obvious when considering that males may occupy their small territories for hours on end. The fact that these territories are usually established hidden in the canopy between the branches of trees (e.g. Hurd, 1955; Gerling et al., 1983) might point to the need for predator avoidance. The above explanation for the correlation between sexual dimorphism and mating strategy is comparable to ecological explanations (Bleiweiss, 1997) for the much debated correlation between sexual size, and plumage dimorphism in lekking birds (e.g. Payne, 1984; Höglund, 1989; Oakes, 1992; Höglund and Sillén-Tullberg, 1994).

\subsection{Selection for different mating strategies}

What factors could influence the evolution and maintenance of different mating strategies in Xylocopa? It is likely that the optimal strategy for a male in search of a female partner depends on the ratio and distribution of receptive females to sexually active males at any one time, i.e. operational sex ratio (OSR, Emlen and Oring, 1977; Ims, 1988; Gerling et al., 1989; Westneat et al., 1990; Andersson, 1994). The OSR is determined by temporal and spatial distribution of receptive females relative to males (Emlen and Oring, 1977), which is influenced by the temporal and spatial distribution of resources, e.g. nesting substrate and food. The OSR, which can vary over time and between populations, is thought to influence the mating strategy, and in turn affects sexual selection (Andersson, 1994).

So why would the OSR vary between species? We provide two, not mutually exclusive possibilities. Firstly, there may be the spatial reasons for differences in OSR. In some species or populations the density of resources (flowers and nests) may be highly clumped, while in others, resources may be widely distributed. A wide distribution of resources would cause a low probability of encountering a receptive female at any one of these resources. Moreover, the large costs of patrolling vast areas necessary to find a potential resource to monopolize would select against resource defence and promote a non-resource based lek mating system. Thus, we hypothesize in areas where resources are widely distributed, non-resource defence strategies are prevalent, whereas when resources are clumped resource defence is preferred.

Secondly, there may be temporal reasons to expect differences in the operational sex ratio between species or populations. In some cases 
the breeding season allows the production of only one generation, either due to high altitudes or to high latitudes. This leads to a highly synchronized life cycle, resulting in a relatively high density of receptive females during a short period of time in spring. Males that patrol flowers or have territories at resources that the receptive females would need to visit have a relatively high probability of encountering such females. Other climates, such as the tropics, allow multiple generations per season leading to asynchronised breeding. In these cases, densities of receptive females at any one time are low and males that defend or patrol resources would have a very low probability of encountering a female, again favouring nonresource based lek displays of males. Thus, we hypothesize that in univoltine species or populations, were the climate allows a single generation to be produced during the breeding season, resource defence strategies are prevalent, whereas in multivoltine populations nonresource based leks are more common.

These two hypotheses can be further investigated by using a phylogenetic approach as used in this paper and by investigating how the operational sex ration influences the preferred mating strategy in species with mixed strategies.

\section{ACKNOWLEDGEMENTS}

We thank Bob Minckley and Hayo Velthuis for suggestions and discussion. Graham Brown and Bryan Danforth for collecting some of the specimens, and John 'Exo' Weylandt for writing Excel macros for analysing BAYESTRAIT output. Earlier parts of this work were supported by Australian Research Council grant no. A19602758 to M. P. Schwarz and an Overseas Postgraduate Research Scholarship to R. Leys at the Flinders University of South Australia.

Évolution corrélée du comportement d'accouplement et de la morphologie chez les abeilles charpentières (Xylocopa $\mathrm{sp.)}$

Xylocopa / évolution corrélée / sélection sexuelle / accouplement / phylogenèse moléculaire / Apidae
Zusammenfassung - Korrelierte Evolution des Paarungsverhaltens und der Morphologie bei großen Holzbienen (Xylocopa sp). Große Holzbienen (Gattung Xylocopa) sind sehr unterschiedlich in ihren Paarungsstrategien. In vielen Untergattungen verteidigen die Männchen Territorien, die Ressourcen für die Weibchen enthalten, wie etwa Blüten oder Nistplätze. In anderen Unterordnungen werden verteilte Paarungsplätze (Leks) gefunden, in denen einzelne Männchen kleine Territorien verteidigen, die keine Ressourcen enthalten. Zusätzlich zu dieser Variation der Paarungsstrategien findet man große Unterschiede in der Morphologie der Männchen und in der Farbverschiedenheit zwischen den Geschlechtern. Die zwei wichtigsten morphologischen Unterschiede sind die Größe der männlichen mesosomalen Drüsen, die ein Paarungspheromon erzeugen und die Größe der Augen der Männchen. Sie können erheblich größer oder gleich groß sein wie die der Weibchen.

Eine auf zwei nuklearen und zwei mitochondrialen Gensequenzen beruhende gut aufgelöste Phylogenie der Untergattungen (Leys, 2002) erlaubt die Nutzung einer Bayesischen Analyse (Bayestraits) zur Untersuchung des Zusammenhangs zwischen den morphologischen Charakteren (Augengröße, mesosomale Drüsengröße und sexuelle Färbung des Männchens) und der Paarungsstrategie.

Wir fanden eine signifikante Assoziation zwischen der Paarungsstrategie und den morphologischen Eigenschaften, sowie eine signifikante korrelative Evolution zwischen den morphologischen Charakteren. Eine Analyse der evolutionären Abläufe legt nahe, dass die Verteidigung von Ressourcen, kleine Drüsen und gleichgestaltige Geschlechter den ursprünglichen Zustand darstellen. Allerdings blieb der ursprüngliche Zustand der Augengröße unklar. Der Zuwachs der Drüsengröße ging offensichtlich der Änderung im Paarungsverhaltens voran oder ist gleichzeitig aufgetreten, während Änderungen des Sexualdimorphismus erst nach den Änderungen des Paarungsverhaltens erfolgten. Sobald sich eine ressourcenunabhängige Verteidigungsstrategie mit den korrelierten morphologischen Veränderungen in Richtung größerer Drüsen, Geschlechtsdimorphismus und normal großen Augen entwickelt hatte, gab es keine Rückkehr zum ursprünglichen Zustand.

Die Assoziation zwischen großen Augen und der Strategie der Ressourcenverteidigung könnte das Ergebnis sexueller Selektion innerhalb des Geschlechts sein, bei der die großen Augen den Männchen ermöglichen, eindringende Männchen rasch zu erkennen und zu verjagen. Ohne diese Möglichkeit auszuschließen ist es ebenfalls möglich, dass große Augen durch sexuelle Selektion zwischen den Geschlechtern entstanden, wenn die Männchen, die Weibchen rasch erkennen, einen Selektionsvorteil haben. Die Assoziation zwischen großen mesosomalen Drüsen und der Verteidigung 
von ressourcenfreien Territorien ist wahrscheinlich ein Resultat von zwischengeschlechtlicher sexueller Selektion, da Männchen mit großen Drüsen Weibchen über größere Entfernungen anlocken können. Wir nehmen weiter an, dass der Färbungsdimorphismus zwischen Männchen und Weibchen das Resultat einer natürlichen Selektion auf kryptische Färbung der Männchen ist.

\section{Korrelierte Evolution / Molekulare Phylogenie / Paarung / Sexuelle Selektion / Xylocopa}

\section{REFERENCES}

Alcock J., Barrows E.M., Gordon G., Hubbard L.J., Kirkendale L., Pyle D.W., Ponder T.L., Zalom K. G. (1978) The ecology and evolution of male reproductive behaviour in the bees and wasps, $\mathrm{J}$. Linn. Soc. Lond. Zool. 64, 293-326.

Alcock J., Johnson M.D. (1990) Female choice in the carpenter bee Xylocopa varipuncta (Hymenoptera: Anthophoridae), J. Zool., Lond. 221, 195-204.

Alcock J., Smith A.P (1987) Hilltopping, leks and female choice in the carpenter bee Xylocopa (Neoxylocopa) varipuncta, J. Zool., Lond. 211, 110.

Andersson M.B. (1994) Sexual selection, Princeton Univ. Press, New Jersey.

Björklund M. (1990) A phylogenetic interpretation of sexual dimorphism in body size and ornament in relation to mating system in birds, J. Evol. Biol. 3, 171-183.

Bleiweiss R. (1997) Covariation of sexual dichromatism and plumage colors in lekking and nonlekking birds - A comparative analysis, Evol. Ecol. $11,217-235$.

Bradbury J.W. (1981) The evolution of leks, in: Alexander R.D., Tinkle D.W. (Eds.), Natural Selection and Social Behavior: Recent Research and New Theory, Chiron Press, New York, pp. 138-169.

Brown W.D., Crespi B.J., Choe J.C. (1997) Sexual conflict and the evolution of mating systems, in: Choe J.C., Crespi B.J. (Eds.), Mating systems in insects and arachnids. Cambridge Univ. Press, Cambridge, pp. 352-377.

Darwin C. (1871) The descent of man and selection in relation to sex, John Murray, London.

Eickwort G.C., Ginsberg H.S. (1980) Foraging and mating behaviour in Apoidea, Annu. Rev. Entomol. 25, 421-446.

Emlen S.T., Oring L.W. (1977) Ecology, sexual selection, and the evolution of animal mating systems, Science 197, 215-223.
Frankie G.W., Vinson S.B, Lewis A. (1979) Territorial behaviour in male Xylocopa micans (Hymenoptera: Anthophoridae), J. Kans. Entomol. Soc. 52, 313-323.

Gerling D., Hurd Jr. P.D., Hefetz A. (1983) Comparative behavioral biology of two Middle East species of carpenter bees (Xylocopa Latreille) (Hymenoptera: Apoidea), Smithson. Contrib. Zool. 369, 1-33.

Gerling D., Velthuis H.H.W., Hefetz A. (1989) Bionomics of the large carpenter bees of the genus Xylocopa, Annu. Rev. Entomol. 34, 163-190.

Hardy I.C.W., Mayhew P.J. (1998) Sex ratio, sexual dimorphism and mating structure in bethylid wasp,. Behav. Ecol. Sociobiol 42, 383-395.

Hefetz A. (1983) Function of secretion of mandibular gland of males in territorial behavior of Xylocopa sulcatipes (Hymenoptera: Anthophoridae), J. Chem. Ecol. 9, 923-931.

Höglund J. (1989) Size and plumage dimorphism in lek-breeding birds: a comparative analysis, Am. Nat. 134, 72-87.

Höglund J., Sillén-Tullberg B. (1994) Does lekking promote the evolution of male biased size dimorphism in birds? On the use of comparative approaches, Am. Nat. 144, 881-889.

Huelsenbeck J.P., Ronquist F. (2001) MRBAYES: Bayesian inference of phylogeny, Bioinformatics 17, 754-755.

Hurd P. Jr., Moure J.S. (1963) A classification of the large carpenter bees (Xylocopini) (Hymenoptera: Apoidea), Univ. California Publ. Entomol. 29, 1365.

Hurd Jr. P.D. (1955) The carpenter bees of California (Hymenoptera: Apoidea), Bull Calif. Insect Survey 4, 35-72.

Ims R.A. (1988) The potential for sexual selection in males: Effect of sex ratio and spatio-temporal distribution of receptive females, Evol. Ecol. 4, 5761.

Johnson K.P., Lanyon S.M. (2000) Evolutionary changes in color patches of blackbirds are associated with marsh nesting, Behav. Ecol. 11, 515519.

Kruger O. (2005) The evolution of reversed sexual size dimorphism in hawks, falcons and owls: A comparative study, Evol. Ecol. 19, 467-486.

Kruger O., Davies N.B., Sorensen M.D. (2007) The evolution of sexual dimorphism in parasitic cuckoos: sexual selection of coevolution? Proc. R. Soc. B 274, 1553-1560.

Leys R. (2000a) A revision of the Australian carpenter bees, genus Xylocopa Latreille, subgenera Koptortosoma Gribodo and Lestis Lepeletier and Serville (Hymenoptera Apidae), Invertebr. Taxon. 14, 115-136.

Leys R. (2000b) Mate locating strategies of the green carpenter bees Xylocopa (Lestis) aeratus, and X. (L.) bombylans, J. Zool. Lond. 252, 453-462. 
Leys R., Cooper S.J.B., Schwarz M.P. (2002) Molecular phylogeny and historical biogeography of the large carpenter bees, genus Xylocopa (Hymenoptera: Apidae), Biol. J. Linn. Soc. 77, 249-266.

Markow T.A. (2002) Female remating, operational sex ratio, and the arena of sexual selection in Drosophila, Evolution 56, 1725-1734.

McAuslane H.J., Vinson S.B., Williams H.J. (1990) Change in mandibular and mesosomal gland contents of male Xylocopa micans (Hymenoptera: Anthophoridae), J. Chem. Ecol. 16, 1877-1885.

Michener C.D. (1990) Castes in Xylocopine bees, in: W. Engels (Ed.), Social insects, an evolutionary approach to castes and reproduction, Berlin Springer Verlag, pp. 123-146.

Minckley R.L. (1994) Comparative morphology of the mesosomal 'gland' in large carpenter bees (Apidae: Xylocopini), Zool. J. Linn. Soc. 53, 291308.

Minckley R.L., Buchmann S.L., Wcislo W.T. (1991) Bioassay evidence for a sex attractant pheromone in the large carpenter bee Xylocopa varipuncta (Hymenoptera: Anthophoridae), J. Zool. Lond. 224, 285-291.

Oakes E.J. (1992) Lekking and the evolution of sexual dimorphism in birds: comparative approaches, Am. Nat. 140, 665-694.

Osten T. (1989) Vergleichend-funktionsmorphologische Untersuchungen des Paarungsverhalten von Platynopoda and Mesotrichia (Hymenoptera: Xylocopini), Stuttgarter Beitr. Naturkd. Ser. A 433, 1-18.

Pagel M., Meade A. (2006) Bayesian analysis of correlated evolution of discrete characters by reversible jump markov chain monte carlo, Am. Nat. 167, $808-825$.

Payne R.B. (1984) Sexual selection, lek and arena behavior, and sexual size dimorphism in birds, Ornithol. Monogr. 33, 1-53.

Posada D., Crandall K.A. (1998) Modeltest: testing the model of DNA substitution, Bioinformatics 14, 817-818.
Rambaut A., Drummond A. (2005) TRACER version 1.3: MCMC Trace File Analyser Program distributed by the authors at http:// evolve.zoo.ox.ac.uk/software.html (accessed on 25 October 2007).

Rodríguez F., Oliver J.F., Marín A., Medina J.R. (1990) The general stochastic model of nucleotide substitutions, J. Theor. Biol. 142, 485-501.

Stark R.E. (1990) Untersuchungen zur Brutbiologie und zum Sozialverhalten der Großen Holzbiene Xylocopa sulcatipes Maa. Dissertation, AlbertLudwigs-Universität Freiburg.

Stuart-Fox D., Moussalli A. (2007) Sex-specific ecomorphological variation and the evolution of sexual dimorphism in dwarf chameleons (Bradypodion spp.), J. Evol. Biol. 20, 1073-1081.

Temeles E.J., Pan I.L., Brennan J.L., Horwitt J.N (2000) Evidence for Ecological Causation of Sexual Dimorphism in a Hummingbird, Science $289,441-443$.

Velthuis H.H.W., Camargo J.M.F. (1975a) Observations on male territories in a carpenter bee Xylocopa (Neoxylocopa) hirsutissima Maidl (Hymenoptera: Anthophoridae), Z. Tierpsychol. 38, 409-418.

Velthuis H.H.W., Camargo J.M.F. (1975b) Further observations on the function of male territories in the carpenter bee Xylocopa (Neoxylocopa) hirsutissima Maidl (Anthophoridae, Hymenoptera), Neth. J. Zool. 25, 516-528.

Velthuis H.H.W., Gerling D. (1980) Observations on territoriality and mating behaviour of the carpenter bee Xylocopa sulcatipes, Entomol. Exp. Appl. 28, 82-91.

Westneat D.F., Sherman P.W., Morton M.L. (1990) The ecology and evolution of extra-pair copulations, Curr. Ornithol. 7, 331-369.

Yang Z. (1996) Among-site rate variation and its impact on phylogenetic analyses, Trends Ecol. Evol. $11,367-372$. 
Online Material 


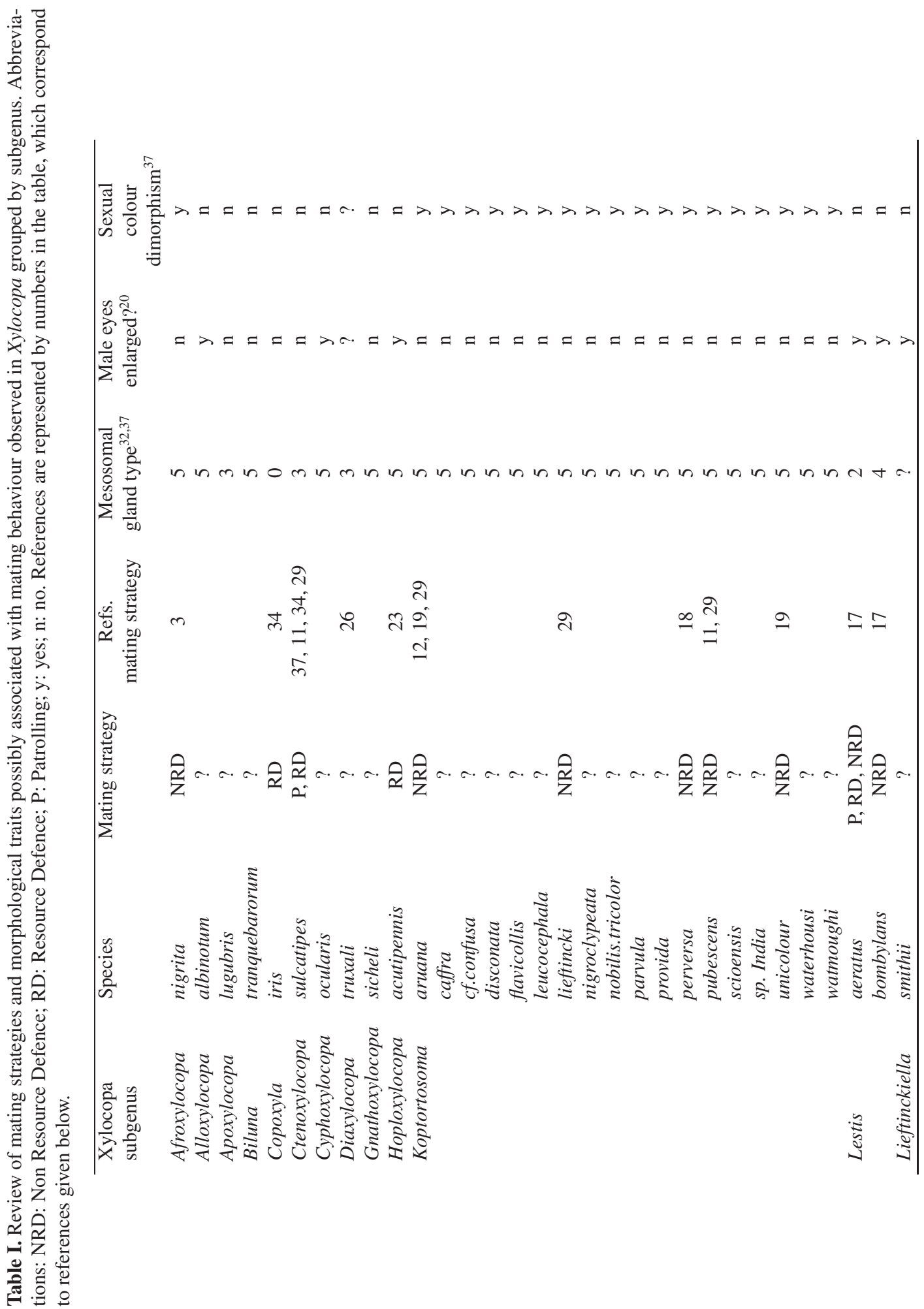




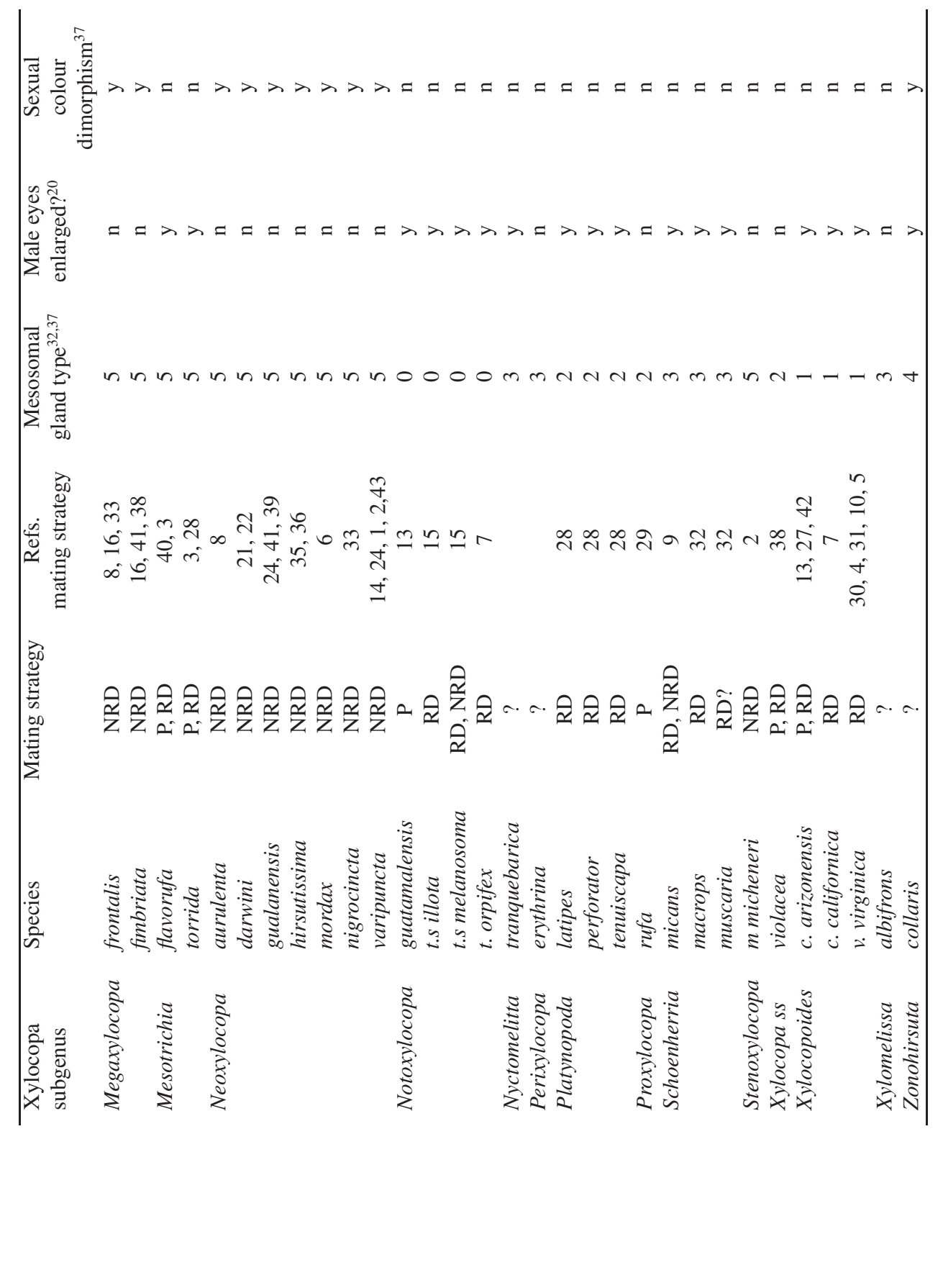


References 1: Alcock and Smith, 1987; 2: Andersen et al., 1988; 3: Anzenberger, 1977; 4: Balduf, 1962; 5: Barrows, 1983; 6: Bennet, 1966; 7: Cruden, 1966; 8: Ducke, 1901; 9: Frankie et al., 1979; 10: Gerling and Hermann, 1978; 11: Gerling et al., 1983; 12: Houston, 1974; 13: Hurd and Moure, 1963; 14: Hurd, 1958; 15: Janzen, 1964; 16: Janzen, 1966; 17: Leys, 2000b; 18: Lieftinck, 1955; 19: Lieftinck, 1956; 20: Lieftinck, 1957; 21: Linsley, 1965; 22: Linsley, 1976; 23: Malyshev, 1931; 24: Marshall and Alcock, 1981; 25: Minckley, 1994; 26: Minckley pers comm; 27: O'Brien and O'Brien, 1966; 28: Osten, 1989; 29: pers obs ; 30: Rau, 1933; 31: Sabrosky, 1962; 32: Sage, 1968; 33: Scholz, 1988; 34: Stark, 1990; 35: Velthuis and Camargo, 1975a; 36: Velthuis and Camargo, 1975b; 37: Velthuis and Gerling, 1980; 38: Vicidomini, 1998; 39: Vinson and Frankie, 1990; 40: Watmough, 1974; 41: Williams et al., 1987; 42: Alcock, 1991; 43: Alcock, 1993.

\section{REFERENCES}

Alcock J. (1991) Mate-locating behaviour of Xylocopa californica arizonensis Cresson (Hymenoptera: Anthophoridae), J. Kans. Entomol. Soc. 64, 349356.

Alcock J. (1993) Differences in site fidelity among territorial males of the carpenter bee Xylocopa varipuncta (Hymenoptera: Anthophoridae), Behaviour 125, 199-217.

Alcock J., Smith A.P. (1987) Hilltopping, leks and female choice in the carpenter bee Xylocopa (Neoxylocopa) varipuncta, J. Zool., Lond. 211, 110.

Andersen J.F., Buchmann S.L., Weisleider D., Plattner R.D., Minckley R.M. (1988) Identification of thoracic gland constituents from male Xylocopa spp. Latreille (Hymenoptera: Anthophoridae) from Arizona, J. Chem. Ecol. 14, 1153-1162.

Anzenberger G. (1977) Ethological study of African carpenter bees of the genus Xylocopa (Hymenoptera, Anthophoridae), Z. Tierpsychol. 44, 337-374.

Balduf W.V. (1962) Life of the carpenter bee, Xylocopa virginica (Linn) (Xylocopidae, Hymenoptera), Ann. Entomol. Soc. Am. 55, 263-271.

Barrows E.M. (1983) Male territoriality in the carpenter bee Xylocopa virginica virginica, Anim. Behav. 31, 806-813.

Bennet F.D. (1966) Observations on the behaviour of males of the West Indian carpenter bees, Xylocopa mordax Smith, on Nevis Island (Hymenoptera: Apidae), Pan-Pac. Entomol. 42, 246.
Cruden R.W. (1966) Observations on the behavior of Xylocopa c. californica and X. tabaniformis orpifex, Pan-Pac. Entomol. 42, 111-119.

Ducke A. (1901) Beobachtungen über Blütenbesuch, Erscheinungszeit der bei Pará vorkommender Bienen, Z.. Syst. Hym. u. Dipt. 1, 49-67.

Frankie G.W., Vinson S.B., Lewis A. (1979) Territorial behaviour in male Xylocopa micans (Hymenoptera: Anthophoridae), J. Kans. Entomol. Soc. 52, 313-323.

Gerling D., Hermann H.R. (1978) Biology and mating behaviour of Xylocopa virginica $\mathrm{L}$. (Hymenoptera, Anthophoridae), Behav. Ecol. Sociobiol. 3, 99-111.

Gerling D., Hurd Jr. P.D., Hefetz A. (1983) Comparative behavioral biology of two Middle East species of carpenter bees (Xylocopa Latreille) (Hymenoptera: Apoidea), Smithson. Contrib. Zool. 369, 1-33.

Houston T.F. (1974) Notes on the behaviour of an Australian carpenter bee, genus Xylocopa Latr. (Hymneoptera: Xylocopinae), Aust. Entomol. Mag. 2, 36-38.

Hurd Jr. P., Moure J.S. (1963) A classification of the large carpenter bees (Xylocopini) (Hymenoptera: Apoidea), Univ. Calif. Publ. Entomol. 29, 1-365.

Hurd Jr. P.D. (1958) Observations on the nesting habits of some new world carpenter bees with remarks on their importance in the problem of species formation (Hymenoptera: Apoidea), Ann. Entomol. Soc. Am. 51, 365-375.

Janzen D.H. (1964) Notes on the behavior of four subspecies of the carpenter bee Xylocopa (Notoxylocopa) tabaniformis, in Mexico, Ann. Entomol. Soc. Am. 57, 296-301.

Janzen D.H. (1966) Notes on the behavior of the carpenter bee Xylocopa fimbriata in Mexico (Hymenoptera: Apoidea), J. Kans. Entomol. Soc. 39, 633-641.

Leys R. (2000b) Mate locating strategies of the green carpenter bees Xylocopa (Lestis) aeratus, and X. (L.) bombylans, J. Zool. Lond. 252, 453-462.

Lieftinck M.A. (1955) The carpenter bees (Xylocopa Latr.) of the Lesser Sunda Islands and Tanimbar, Verhand. Naturforsch. Ges. Basel 66, 5-32.

Lieftinck M.A. (1956) Revision of the carpenter bees (Xylocopa Latr.) of the Moluccan islands, with notes on other Indo-Australian species, Tijdschr. Entomol. 99, 55-73.

Lieftinck, M.A. (1957) Revision of the carpenter-bees (Xylocopa Latr., subgenus Maiella Michener) of the Papuan region (Hymenoptera, Apoidea), Nova Guin. (ns) 8, 325-376.

Linsley E.G. (1965) Notes on male territorial behavior in the Galápagos carpenter bee (Hymenoptera: Apidae), Pan-Pac. Entomol. 41, 158-161.

Linsley E.G. (1976) Defensive behavior of males about plants not visited by their females (Hymenoptera, Apoidea), Pan-Pac. Entomol. 52, 177-178. 
Malyshev S.J. (1931) Lebensgeschichte der Holzbienen, Xylocopa Latr. (Apoidea), Z. Morphol. u. Ökol. der Tiere 23, 754-809.

Marshall L.D., Alcock J. (1981) The evolution of the mating system of the Carpenter bee Xylocopa varipuncta (Hymenoptera: Anthophoridae), J. Zool., Lond. 193, 315-324.

Minckley R.L. (1994) Comparative morphology of the mesosomal 'gland' in large carpenter bees (Apidae: Xylocopini), Zool. J. Linn. Soc. 53, 291308.

O'Brien L.B., O'Brien C.W. (1966) Observations on territoriality and the new nesting substrate of Xylocopa californica arizonensis Cresson, PanPac. Entomol. 42, 27-29.

Osten T. (1989) Vergleichend-funktionsmorphologische Untersuchungen des Paarungsverhaltens von Platynopoda and Mesotrichia (Hymenoptera: Xylocopini), Stuttgarter Beitr. Naturkd. Ser. A 433, 1-18.

Rau P. (1933) The jungle bees and wasps of Barro Colorado Island (with notes on other insects), Privately printed, Kirkwood, Mo, pp. 1-324.

Sabrosky C.W. (1962) Mating in Xylocopa virginica (Hymenoptera: Apidae), Proc. Entomol. Soc. Wash. 64, 184.

Sage R.D. (1968) Observations on feeding, nesting and territorial behaviour of carpenter bees genus Xylocopa in Costa Rica, Ann. Entomol. Soc. Am. $61,884-889$.

Scholz E. (1988) Artenspektrum, Verbreitung, Bionomie und Paarungsbiologie von Holzbienen (Apoidea: Xylocopinae) in Río Grande do Sul, Südbrasilien. Diplomarbeit, Eberhard-KarlsUniversität Tübingen.
Stark R.E. (1990) Untersuchungen zur Brutbiologie und zum Sozialverhalten der Großen Holzbiene Xylocopa sulcatipes Maa. Dissertation, AlbertLudwigs-Universität Freiburg.

Velthuis H.H.W., Camargo J.M.F. (1975a) Observations on male territories in a carpenter bee Xylocopa (Neoxylocopa) hirsutissima Maidl (Hymenoptera: Anthophoridae), Z. Tierpsychol. $38,409-418$.

Velthuis H.H.W., Camargo J.M.F. (1975b) Further observations on the function of male territories in the carpenter bee Xylocopa (Neoxylocopa) hirsutissima Maidl (Anthophoridae, Hymenoptera), Neth. J. Zool. 25, 516-528.

Velthuis H.H.W., Gerling D. (1980) Observations on territoriality and mating behaviour of the carpenter bee Xylocopa sulcatipes, Entomol. Exp. Appl. 28, 82-91.

Vicidomini S. (1998) Biology of Xylocopa (Xylocopa) violacea (L., 1758) (Hymenoptera: Apidae): Copulatory behavior. Atti Mus. Civ. Orn. Sc. At. Varenna 3, 16-33.

Vinson S.B., Frankie G.W. (1990) Territorial and mating behaviour of Xylocopa fimbriata $\mathrm{F}$. and Xylocopa gualanensis Cockerell from Costa Rica, J. Insect Behav. 3, 13-31.

Watmough R.H. (1974) Biology and behaviour of carpenter bees in southern Africa, J. Entomol. Soc. S. Afr. 37, 261-281.

Williams H.J., Vinson S.B., Frankie G.W. (1987) Chemical content of the dorsal mesosomal gland of two Xylocopa species (Hymenoptera: Anthophoridae) from Costa Rica, Comp. Biochem. Physiol. 86B, 311. 
Table II. Parameter estimates of Bayesian phylogenetic analysis.

\begin{tabular}{lcc} 
Run & Arithmetic mean & Harmonic mean \\
\hline 1 & -19675.05 & -19733.32 \\
2 & -19674.99 & -19737.05 \\
\hline TOTAL & -19675.02 & -19736.38 \\
\hline
\end{tabular}

Model parameter summaries over the runs sampled in files

"XylocopaCorr.run1.p" and "XylocopaCorr.run2.p":

(Summaries are based on a total of 34070 samples from 2 runs)

(Each run produced 47035 samples of which 17035 samples were included)

\begin{tabular}{lcccccc} 
& & & \multicolumn{2}{c}{ 95\% Cred. Interval } & & \\
Parameter & Mean & Variance & Lower & Upper & Median & PSRF $*$ \\
\hline $\mathrm{TL}\{$ all $\}$ & 8.779483 & 0.687544 & 7.219000 & 10.420000 & 8.752000 & \\
$\mathrm{r}(\mathrm{A}<->\mathrm{C})\{1\}$ & 0.112369 & 0,000621 & 0.069289 & 0.164658 & 0.111548 & 1.010 \\
$\mathrm{r}(\mathrm{A}<->\mathrm{G})\{1\}$ & 0.051007 & 0.000422 & 0.021393 & 0.102631 & 0.047685 & 1.001 \\
$\mathrm{r}(\mathrm{A}<->\mathrm{T})\{1\}$ & 0.013063 & 0.000041 & 0.003677 & 0.028720 & 0.012014 & 1.000 \\
$\mathrm{r}(\mathrm{C}<->\mathrm{G})\{1\}$ & 0.021660 & 0.000263 & 0.001731 & 0.063810 & 0.018279 & 1.000 \\
$\mathrm{r}(\mathrm{C}<->\mathrm{T})\{1\}$ & 0.794912 & 0.001701 & 0.706104 & 0.867219 & 0.796851 & 1.013 \\
$\mathrm{r}(\mathrm{G}<->\mathrm{T})\{1\}$ & 0.006989 & 0.000013 & 0.002167 & 0.015557 & 0.006296 & 1.001 \\
$\mathrm{r}(\mathrm{A}<->\mathrm{C})\{2\}$ & 0.096272 & 0.001016 & 0.044802 & 0.169145 & 0.092903 & 1.000 \\
$\mathrm{r}(\mathrm{A}<->\mathrm{G})\{2\}$ & 0.255903 & 0.004784 & 0.133134 & 0.408959 & 0.251509 & 1.000 \\
$\mathrm{r}(\mathrm{A}<->\mathrm{T})\{2\}$ & 0.177007 & 0.001907 & 0.095485 & 0.266608 & 0.175866 & 1.002 \\
$\mathrm{r}(\mathrm{C}<->\mathrm{G})\{2\}$ & 0.208175 & 0.003862 & 0.106625 & 0.347642 & 0.200665 & 1.008 \\
$\mathrm{r}(\mathrm{C}<->\mathrm{T})\{2\}$ & 0.224610 & 0.002222 & 0.142442 & 0.326634 & 0.221255 & 1.003 \\
$\mathrm{r}(\mathrm{G}<->\mathrm{T})\{2\}$ & 0.038034 & 0.000422 & 0.008934 & 0.086124 & 0.034424 & 1.003 \\
$\mathrm{r}(\mathrm{A}<->\mathrm{C})\{3\}$ & 0.013211 & 0.000034 & 0.003452 & 0.025669 & 0.012825 & 1.000 \\
$\mathrm{r}(\mathrm{A}<->\mathrm{G})\{3\}$ & 0.613002 & 0.003497 & 0.492473 & 0.718462 & 0.615827 & 1.002 \\
$\mathrm{r}(\mathrm{A}<->\mathrm{T})\{3\}$ & 0.014893 & 0.000004 & 0.011223 & 0.019204 & 0.014830 & 1.003 \\
$\mathrm{r}(\mathrm{C}<->\mathrm{G})\{3\}$ & 0.063412 & 0.002861 & 0.002438 & 0.196259 & 0.051643 & 1.000 \\
$\mathrm{r}(\mathrm{C}<->\mathrm{T})\{3\}$ & 0.234765 & 0.001916 & 0.155871 & 0.324267 & 0.231882 & 1.024 \\
\hline & & & & & &
\end{tabular}


Table II. Continued.

\begin{tabular}{lcccccc} 
& & & \multicolumn{2}{c}{$95 \%$ Cred. Interval } & & \\
Parameter & Mean & Variance & Lower & Upper & Median & PSRF * \\
\hline $\mathrm{r}(\mathrm{G}<->\mathrm{T})\{3\}$ & 0.060716 & 0.000428 & 0.022300 & 0.104037 & 0.060407 & 1.001 \\
$\mathrm{r}(\mathrm{A}<->\mathrm{C})\{4\}$ & 0.062820 & 0.000564 & 0.022659 & 0.114832 & 0.060479 & 1.030 \\
$\mathrm{r}(\mathrm{A}<->\mathrm{G})\{4\}$ & 0.375706 & 0.004909 & 0.254136 & 0.521033 & 0.372457 & 1.006 \\
$\mathrm{r}(\mathrm{A}<->\mathrm{T})\{4\}$ & 0.082565 & 0.001743 & 0.018229 & 0.178472 & 0.076618 & 1.001 \\
$\mathrm{r}(\mathrm{C}<->\mathrm{G})\{4\}$ & 0.092084 & 0.000339 & 0.057797 & 0.130533 & 0.091245 & 1.005 \\
$\mathrm{r}(\mathrm{C}<->\mathrm{T})\{4\}$ & 0.363019 & 0.003908 & 0.239945 & 0.485248 & 0.363004 & 1.001 \\
$\mathrm{r}(\mathrm{G}<->\mathrm{T})\{4\}$ & 0.023807 & 0.000230 & 0.001737 & 0.059532 & 0.021357 & 1.002 \\
$\mathrm{r}(\mathrm{A}<->\mathrm{C})\{5\}$ & 0.040681 & 0.001605 & 0.000991 & 0.149261 & 0.027360 & 1.006 \\
$\mathrm{r}(\mathrm{A}<->\mathrm{G})\{5\}$ & 0.200097 & 0.010910 & 0.047166 & 0.433351 & 0.183449 & 1.000 \\
$\mathrm{r}(\mathrm{A}<->\mathrm{T})\{5\}$ & 0.084731 & 0.003795 & 0.009080 & 0.233286 & 0.071700 & 1.012 \\
$\mathrm{r}(\mathrm{C}<->\mathrm{G})\{5\}$ & 0.044020 & 0.001820 & 0.001236 & 0.159704 & 0.030565 & 1.007 \\
$\mathrm{r}(\mathrm{C}<->\mathrm{T})\{5\}$ & 0.589048 & 0.015706 & 0.319630 & 0.811595 & 0.596169 & 1.000 \\
$\mathrm{r}(\mathrm{G}<->\mathrm{T})\{5\}$ & 0.041423 & 0.001851 & 0.001049 & 0.163538 & 0.027983 & 1.019 \\
$\mathrm{r}(\mathrm{A}<->\mathrm{C})\{6\}$ & 0.081490 & 0.000399 & 0.046834 & 0.124267 & 0.079896 & 1.000 \\
$\mathrm{r}(\mathrm{A}<->\mathrm{G})\{6\}$ & 0.407030 & 0.002136 & 0.318991 & 0.499779 & 0.406476 & 1.001 \\
\hline
\end{tabular}


Table II. Continued.

\begin{tabular}{|c|c|c|c|c|c|c|}
\hline \multirow[b]{2}{*}{ Parameter } & \multirow[b]{2}{*}{ Mean } & \multirow[b]{2}{*}{ Variance } & \multicolumn{2}{|c|}{ 95\% Cred. Interval } & \multirow[b]{2}{*}{ Median PSRF * } & \\
\hline & & & Lower & Upper & & \\
\hline $\mathrm{r}(\mathrm{A}<->\mathrm{T})\{6\}$ & 0.050203 & 0.000224 & 0.025091 & 0.083121 & 0.048919 & 1.006 \\
\hline $\mathrm{r}(\mathrm{C}<->\mathrm{G})\{6\}$ & 0.050844 & 0.000296 & 0.022321 & 0.089896 & 0.048986 & 1.001 \\
\hline $\mathrm{r}(\mathrm{C}<->\mathrm{T})\{6\}$ & 0.381123 & 0.002132 & 0.294647 & 0.476833 & 0.379447 & 1.000 \\
\hline $\mathrm{r}(\mathrm{G}<->\mathrm{T})\{6\}$ & 0.029309 & 0.000154 & 0.009693 & 0.057428 & 0.027967 & 1.006 \\
\hline $\mathrm{r}(\mathrm{A}<->\mathrm{C})\{7\}$ & 0.037773 & 0.000379 & 0.009256 & 0.084751 & 0.034703 & 1.000 \\
\hline $\mathrm{r}(\mathrm{A}<->\mathrm{G})\{7\}$ & 0.169124 & 0.005341 & 0.053785 & 0.329398 & 0.162051 & 1.000 \\
\hline $\mathrm{r}(\mathrm{A}<->\mathrm{T})\{7\}$ & 0.074377 & 0.001246 & 0.022607 & 0.158782 & 0.069160 & 1.021 \\
\hline $\mathrm{r}(\mathrm{C}<->\mathrm{G})\{7\}$ & 0.033613 & 0.000316 & 0.008199 & 0.074750 & 0.030584 & 1.011 \\
\hline $\mathrm{r}(\mathrm{C}<->\mathrm{T})\{7\}$ & 0.671894 & 0.011300 & 0.455748 & 0.857869 & 0.678300 & 1.006 \\
\hline $\mathrm{r}(\mathrm{G}<->\mathrm{T})\{7\}$ & 0.013220 & 0.000210 & 0.000308 & 0.052949 & 0.008386 & 1.025 \\
\hline $\mathrm{r}(\mathrm{A}<->\mathrm{C})\{8\}$ & 0.048663 & 0.000102 & 0.030929 & 0.070850 & 0.047918 & 1.004 \\
\hline $\mathrm{r}(\mathrm{A}<->\mathrm{G})\{8\}$ & 0.423534 & 0.002438 & 0.327377 & 0.523401 & 0.422860 & 1.000 \\
\hline $\mathrm{r}(\mathrm{A}<->\mathrm{T})\{8\}$ & 0.038660 & 0.000053 & 0.025624 & 0.054482 & 0.038173 & 1.000 \\
\hline $\mathrm{r}(\mathrm{C}<->\mathrm{G})\{8\}$ & 0.080449 & 0.000380 & 0.045761 & 0.122542 & 0.079069 & 1.000 \\
\hline $\mathrm{r}(\mathrm{C}<->\mathrm{T})\{8\}$ & 0.352954 & 0.002123 & 0.265318 & 0.445379 & 0.351967 & 1.001 \\
\hline $\mathrm{r}(\mathrm{G}<->\mathrm{T})\{8\}$ & 0.055741 & 0.000163 & 0.033524 & 0.082830 & 0.054637 & 1.000 \\
\hline $\operatorname{pi}(\mathrm{A})\{1\}$ & 0.428037 & 0.000529 & 0.383241 & 0.473599 & 0.427800 & 1.001 \\
\hline
\end{tabular}


Table II. Continued.

\begin{tabular}{|c|c|c|c|c|c|c|}
\hline \multirow{3}{*}{$\begin{array}{l}\& \\
\text { Parameter } \\
\text { pi }(\mathrm{C})\{1\}\end{array}$} & \multicolumn{4}{|c|}{ 95\% Cred. Interval } & \multirow[b]{2}{*}{ Median PSRF * } & \\
\hline & Mean & Variance & Lower & Upper & & \\
\hline & 0.038358 & 0.000021 & 0.030387 & 0.048404 & 0.038124 & 1.006 \\
\hline $\operatorname{pi}(G)\{1\}$ & 0.111994 & 0.000257 & 0.083206 & 0.145683 & 0.110975 & 1.001 \\
\hline $\operatorname{pi}(\mathrm{T})\{1\}$ & 0.421610 & 0.000494 & 0.377582 & 0.466440 & 0.421511 & 1.003 \\
\hline $\operatorname{pi}(\mathrm{A})\{2\}$ & 0.242157 & 0.000450 & 0.202538 & 0.285620 & 0.241576 & 1.001 \\
\hline $\operatorname{pi}(C)\{2\}$ & 0.194525 & 0.000526 & 0.149748 & 0.239084 & 0.194705 & 1.001 \\
\hline $\operatorname{pi}(\mathrm{G})\{2\}$ & 0.114903 & 0.000290 & 0.083922 & 0.149458 & 0.114232 & 1.000 \\
\hline $\operatorname{pi}(\mathrm{T})\{2\}$ & 0.448415 & 0.000726 & 0.395589 & 0.501658 & 0.447774 & 1.003 \\
\hline $\operatorname{pi}(\mathrm{A})\{3\}$ & 0.404215 & 0.000711 & 0.355534 & 0.454808 & 0.404472 & .1001 \\
\hline $\operatorname{pi}(\mathrm{C})\{3\}$ & 0.035908 & 0.000009 & 0.030344 & 0.042173 & 0.035846 & 1.003 \\
\hline $\operatorname{pi}(G)\{3\}$ & 0.009735 & 0.000001 & 0.007921 & 0.011793 & 0.009744 & 1.000 \\
\hline $\operatorname{pi}(\mathrm{T})\{3\}$ & 0.550141 & 0.000647 & 0.501308 & 0.596874 & 0.549151 & 1.001 \\
\hline $\operatorname{pi}(\mathrm{A})\{4\}$ & 0.146698 & 0.000304 & 0.113993 & 0.183037 & 0.145792 & 1.003 \\
\hline $\operatorname{pi}(\mathrm{C})\{4\}$ & 0.347579 & 0.000611 & 0.300667 & 0.397268 & 0.347347 & 1.001 \\
\hline $\operatorname{pi}(G)\{4\}$ & 0.321533 & 0.000603 & 0.275524 & 0.371519 & 0.321403 & 1.001 \\
\hline $\operatorname{pi}(\mathrm{T})\{4\}$ & 0.184190 & 0.000377 & 0.148775 & 0.224521 & 0.183522 & 1.001 \\
\hline $\operatorname{pi}(\mathrm{A})\{5\}$ & 0.323336 & 0.001502 & 0.250276 & 0.402432 & 0.322468 & 1.000 \\
\hline $\operatorname{pi}(\mathrm{C})\{5\}$ & 0.158196 & 0.000854 & 0.103939 & 0.218940 & 0.156910 & 1.003 \\
\hline
\end{tabular}


Table II. Continued.

\begin{tabular}{|c|c|c|c|c|c|c|}
\hline \multirow{3}{*}{$\frac{\text { Parameter }}{\text { pi }(G)\{5\}}$} & \multirow[b]{2}{*}{ Mean } & \multirow[b]{2}{*}{ Variance } & \multicolumn{2}{|c|}{ 95\% Cred. Interval } & \multirow[b]{2}{*}{ Median } & \multirow[b]{2}{*}{$\operatorname{PSRF} *$} \\
\hline & & & Lower & Upper & & \\
\hline & 0.332876 & 0.001545 & 0.258305 & 0.412160 & 0.332285 & 1.004 \\
\hline $\operatorname{pi}(\mathrm{T})\{5\}$ & 0.185593 & 0.000979 & 0.127806 & 0.250591 & 0.184299 & 1.000 \\
\hline $\operatorname{pi}(\mathrm{A})\{6\}$ & 0.290421 & 0.000468 & 0.249253 & 0.333817 & 0.290136 & 1.001 \\
\hline $\operatorname{pi}(C)\{6\}$ & 0.204093 & 0.000354 & 0.168607 & 0.241517 & 0.203425 & 1.001 \\
\hline $\operatorname{pi}(G)\{6\}$ & 0.235874 & 0.000425 & 0.196190 & 0.277738 & 0.235236 & 1.001 \\
\hline $\operatorname{pi}(\mathrm{T})\{6\}$ & 0.269612 & 0.000477 & 0.227634 & 0.312887 & 0.269387 & 1.001 \\
\hline $\operatorname{pi}(\mathrm{A})\{7\}$ & 0.260945 & 0.001079 & 0.198707 & 0.325811 & 0.260582 & 1.001 \\
\hline $\operatorname{pi}(\mathrm{C})\{7\}$ & 0.256270 & 0.000915 & 0.199644 & 0.317484 & 0.255451 & 1.000 \\
\hline $\operatorname{pi}(\mathrm{G})\{7\}$ & 0.292924 & 0.001084 & 0.231231 & 0.360152 & 0.291757 & 1.001 \\
\hline $\operatorname{pi}(\mathrm{T})\{7\}$ & 0.189861 & 0.000695 & 0.139949 & 0.243389 & 0.188870 & 1.002 \\
\hline $\operatorname{pi}(\mathrm{A})\{8\}$ & 0.355836 & 0.000312 & 0.321834 & 0.390724 & 0.355916 & 1.000 \\
\hline $\operatorname{pi}(\mathrm{C})\{8\}$ & 0.180193 & 0.000165 & 0.156054 & 0.205723 & 0.180128 & 1.000 \\
\hline $\operatorname{pi}(\mathrm{G})\{8\}$ & 0.127815 & 0.000146 & 0.105416 & 0.152289 & 0.127215 & 1.001 \\
\hline $\operatorname{pi}(\mathrm{T})\{8\}$ & 0.336156 & 0.000269 & 0.304747 & 0.369591 & 0.335750 & 1.003 \\
\hline alpha $\{1\}$ & 0.374723 & 0.001001 & 0.320808 & 0.445366 & 0.371787 & 1.000 \\
\hline alpha $\{2\}$ & 0.249544 & 0.001008 & 0.196770 & 0.323391 & 0.246126 & 1.001 \\
\hline alpha $\{3\}$ & 0.649272 & 0.008335 & 0.487113 & 0.842118 & 0.644745 & 1.000 \\
\hline
\end{tabular}


Table II. Continued.

\begin{tabular}{|c|c|c|c|c|c|c|}
\hline \multirow[b]{2}{*}{ Parameter } & \multirow[b]{2}{*}{ Mean } & \multirow[b]{2}{*}{ Variance } & \multicolumn{2}{|c|}{$95 \%$ Cred. Interval } & \multirow[b]{2}{*}{ Median } & \multirow[b]{2}{*}{ PSRF * } \\
\hline & & & Lower & Upper & & \\
\hline alpha $\{4\}$ & 0.217063 & 0.000866 & 0.168658 & 0.285333 & 0.213694 & 1.000 \\
\hline alpha $\{5\}$ & 0.084999 & 0.002159 & 0.058555 & 0.217518 & 0.072806 & 1.003 \\
\hline alpha $\{6\}$ & 0.181063 & 0.000479 & 0.147253 & 0.232184 & 0.178055 & 1.002 \\
\hline alpha $\{7\}$ & 0.233658 & 0.002005 & 0.150098 & 0.324325 & 0.233085 & 1.002 \\
\hline alpha $\{8\}$ & 0.425522 & 0.003315 & 0.328848 & 0.557341 & 0.419544 & 1.005 \\
\hline $\operatorname{pinvar}\{1\}$ & 0.371875 & 0.001559 & 0.291913 & 0.444438 & 0.373336 & 1.008 \\
\hline $\operatorname{pinvar}\{2\}$ & 0.591231 & 0.001979 & 0.488309 & 0.666592 & 0.594942 & 1.000 \\
\hline $\operatorname{pinvar}\{3\}$ & 0.163154 & 0.004724 & 0.029792 & 0.303027 & 0.163397 & 1.000 \\
\hline $\operatorname{pinvar}\{4\}$ & 0.427249 & 0.002326 & 0.331804 & 0.521197 & 0.427681 & 1.008 \\
\hline $\operatorname{pinvar}\{5\}$ & 0.861554 & 0.002266 & 0.756254 & 0.940949 & 0.866164 & 1.002 \\
\hline $\operatorname{pinvar}\{6\}$ & 0.219999 & 0.002272 & 0.123029 & 0.310939 & 0.220676 & 1.005 \\
\hline $\operatorname{pinvar}\{7\}$ & 0.321978 & 0.006379 & 0.156628 & 0.467567 & 0.325644 & 1.000 \\
\hline $\operatorname{pinvar}\{8\}$ & 0.011613 & 0.000124 & 0.000333 & 0.041088 & 0.008251 & 1.001 \\
\hline
\end{tabular}

* Convergence diagnostic (PSRF $=$ Potential scale reduction factor [Gelman and Rubin, 1992], uncorrected) should approach 1 as runs converge. The values may be unreliable if you have a small number of samples. PSRF should only be used as a rough guide to convergence since all the assumptions that allow one to interpret it as a scale reduction factor are not met in the phylogenetic context. 

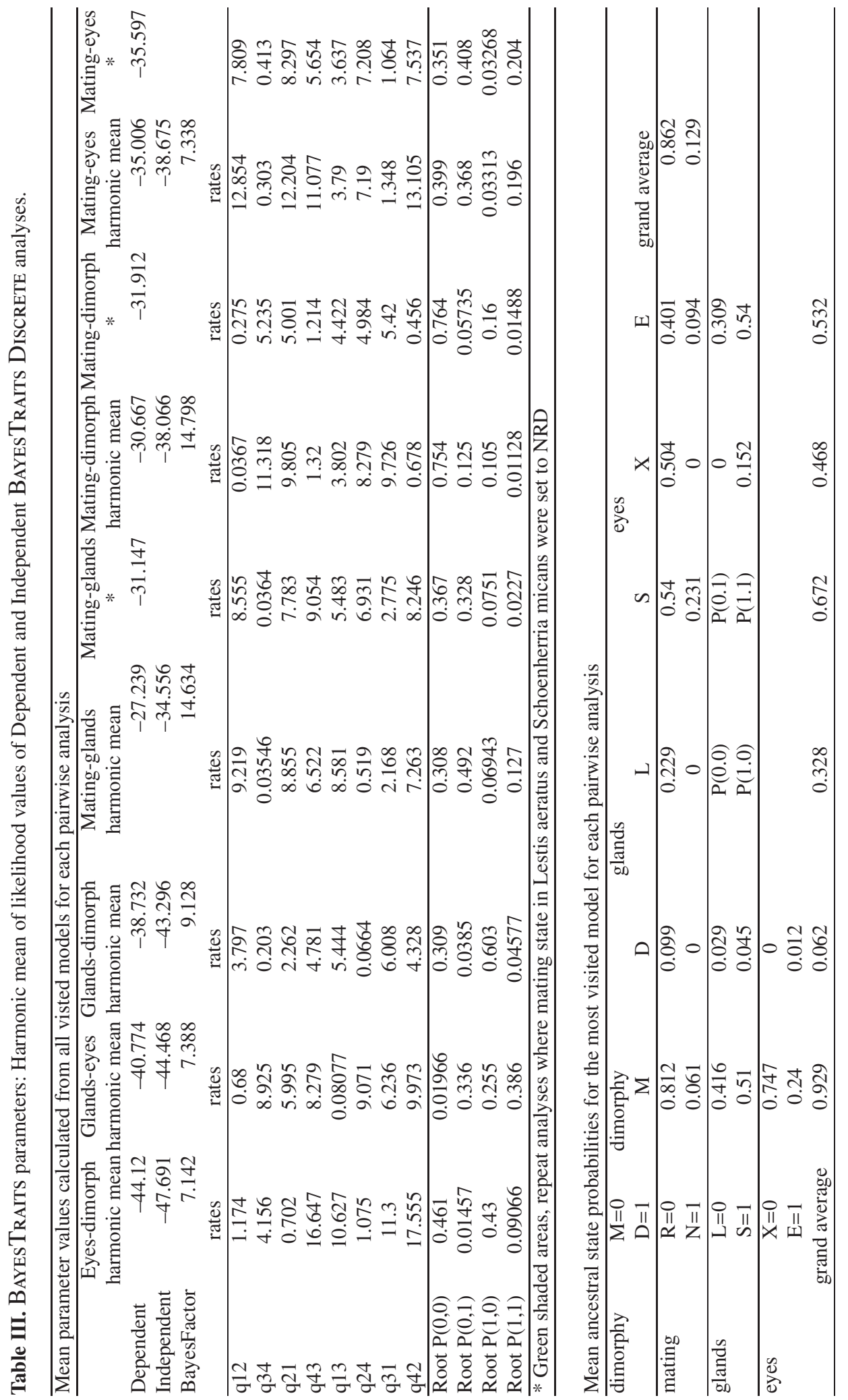